Agnieszka Dauksza

Uniwersytet Jagielloński*

iD https://orcid.org/0000-0001-8269-6096

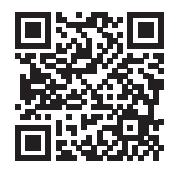

\title{
Blurred Waters of the Biographical Element. Editorial Introduction
}

\begin{abstract}
Inspired by Clifford Geertz's concept, the author analyses blurred genres on the example of biographies, focusing on their contemporary transformations, while scrutinizing their formal, methodological and audience-related (possible reasons behind their popularity) aspects. The ethical dimension of the biographer's work is crucial, and here it is examined from the perspective of the writer's personal involvement and the emotional community of readers (as defined by Barbara Rosenwein). The study also analyses biographies when they are perceived as a type of testimony, experience, an act of creating potential histories, or as critical works. From this perspective, writing a biography is like inciting comprehension by re-evaluating the meaning of somebody's experiences and engaging them with the modern readers' experience. In all probability, the key is not the authenticity of the presented reality, but enabling the reader to immerse themselves in the flow of the story so that reading the book becomes a significant experience in itself. What the reader seems to require is for the devices that are typical for novel-like narration to be combined with nonfictional forms. Thus, genre blurring is, in fact, a basis for renegotiating the pact between authors and readers, where both sides are well aware of how ambiguous it is to write about an absent third party, realizing that it is necessary to omit facts, be concise, make sense of convoluted events, and to extract the essence in things that seemingly look chaotic.
\end{abstract}


* Uniwersytet Jagielloński, Wydział Polonistyki ul. Golębia 16, 31-007 Kraków

e-mail: agnieszka.dauksza@uj.edu.pl

This study was co-funded by the Heritage PRA (Priority Research Area) within the framework of the Strategic Program Excellence Initiative at Jagellonian University (1 st edition). 


\section{Blurred genres and methodology}

When framing the concept of blurred genres, Clifford Geertz writes about "the present jumbling of varieties" (1990: 114), which reflects the nature of life perceived as "a bowl of strategies" (p. 119). This diagnosis also applies when one analyses modern biographies, the popularity of which is highly revealing of readers' preferences. The question arises, however, about the nature of this blurring, the grounds on which it could be implemented, and the signs of its use. As indicated by experts in the genre, blurring biographies is undoubtedly a progressive process, with them being blended with aspects of reportage, novels, and autobiographies (cf. Całek, Nasiłowska, Tabaszewska 2019). On the one hand, this reinforces the interventional, critical and investigative function, thereby often intensifying the biographer's presence, while on the other hand, it consolidates the tendency to add elements of fiction to the biographical story ${ }^{1}$.

Biographies seem to have always been polyphonic and hybrid narratives. They have combined practices aimed at the interpretation of textual, visual, material, and recollective constituents. They utilise elements of historical, literary, psychological and art historical analysis, incorporating scientific, epistolary and intimist forms, while balancing the delineation of a given biographee and the interventional creation of a (slightly) different perception of their deeds - even when the presence of the biographer's subjective perspective was meticulously concealed. The key question, however, is not how parasitic biographies use other genres, but for what purposes. Individual cases should be examined contextually with regard to the range of strategies applied by the biographer. Broadly speaking, however, departure from or intensification of the biographical formula (depending on how one interprets current transformations within the genre) is beyond any doubt an expression of the ongoing search for a more capacious literary format, where capacious should denote a form that allows the biographer to create a convincing image of a given biographee.

Essentially, modern biographical literature in Poland fits squarely into clearly defined types of storytelling - these are either realistic accounts that accurately depict all elements of the presented world and aspire to provide a holistic picture, or at least a fragmentary

1 Progressive fictionalisation of the genre and its faction variant are discussed by Justyna Tabaszewska cf. Tabaszewska 2019. 
narrative that focuses on a chosen aspect of the biographee's activity or depicts their life through the prism of a particular relationship. At times, this fragmentariness goes hand in hand with an inventiveness of the form, i.e., searching for means that would reflect or generate the effect of a given biographee by referring to their literary or artistic practices. Having an extended (capacious) agenda also renders it easier for the biographer to accomplish their primary objectives - to successfully complete the core task of presenting a well-rounded biography and to consider multiple hypotheses to resolve any issues that arise. Tensions between these motivations may also require the application of devices beyond those traditionally used for biographies, whether they are articulated by the biographer or not. Naturally, biographers are also swayed by reviewers, market requirements, editorial suggestions, responsibilities towards heirs and beneficiaries, and finally, the pressure exerted by guardians of remembrance and their expectations, i.e., the community of those who commemorate a given biographee and foster their firmly established image. Biographies are never written in vacuo, and it would be difficult to find another genre so burdened with responsibility for the biographer: an obligation of meticulousness and accuracy concerning the archival data, while, at the same time, introducing a certain inventiveness or attractiveness of the message. When the relationality of the biography and the degree to which the author is entangled in conveying the symbolic, material, political and recollective message are taken into account, one could ask: as societal norms, so biographies? This is not necessarily true, but this jumbling of the biographical format - its constituents and relationships between them - does indirectly reveal both the authors' and readers' expectations, their perceptions, and the boundaries of their experiences. The popularity of biographies is obviously not a new trend, which makes one wonder why in this period where we see such a dramatic collapse in overall readership people decide to opt for a biographical book. This appetite is confirmed not only by surveys but also by the relatively high print runs of these publications. Risking overgeneralisation, one may still distinguish several fundamental reasons.

Firstly, there is authenticity and immediacy, which fosters a feeling of intimacy with the depicted person, the illusion that the reader participates in the presented reality. After all, a biography is "writing life", as indicated by its Greek etymology. This not only applies to writing and creating it but also to the reader, who actively presumes meaning while reading, inevitably taking the position of a witness to the life story being told. Secondly, both writing and reading biographies requires comprehending new, and perhaps otherwise inaccessible, times, social groups and environments, which no longer constitute an abstract backdrop, but have become tangible, complex, and fascinating, adding to the biographee's experience. What matters is not only the cognitive aspect, but also the attempt to experience the past reality, i.e., the almost investigative task of using the archival data to reconstruct the standards of functioning in a given emotional community, all the norms, motivations, and scenarios of emotional behaviour, the background of which makes the biographee's fates and fortunes more explicit and comprehensible ${ }^{2}$.

Another reason is the pure satisfaction of meeting the biographee. It may stem from the reader's desire to transcend the boundaries of their own life experiences or an interest in other people's (sometimes quite distant and colourful) affairs. This urge might be related to the need to identify - the reader's fantasy that here they step into the shoes of an outstanding

2 Cf. the concept of research into emotional communities, as proposed by Barbara Rosenwein (2015). 
figure and can see the world through their eyes. Besides this, yet another motivator could be a voyeuristic impulse, the pleasure of peeking into somebody's private life and personal matters. Naturally, this is linked to another effect of biographies: treating the biographee as an icon, whose life, traits, behaviour, habits and actions can inspire contemporary readers. A biography can also facilitate comprehension of the biographee's works, change the way they are interpreted, demystify the biographee's accepted image, or even deconstruct the self-image they fostered during their lifetime.

Another question is whether the reader's needs extend beyond this sense of authenticity. Judging by the numbers of copies sold, common opinions, online comments, and professional reviews, a factor that determines the success of a given biography is more likely the ability to link diverse elements, i.e., it is insufficient only to provide known facts and themes, as readers' wishes to be exposed to what is surprising and transcends beyond the accepted perception and assessment of a given biographee. It also requires the author to access various media and information channels, and to exercise an innovative approach to archival data by blurring existing source material. From this perspective, writing a biography is like inciting comprehension by re-evaluating the meaning of somebody's experiences and engaging them with the modern readers' experience ${ }^{3}$. In all probability, the key is not the authenticity of the presented reality, but enabling the reader to immerse themselves in the flow of the story so that reading the book becomes a significant experience in itself. What the reader seems to require is for the devices that are typical for novel-like narration to be combined with nonfictional forms. Thus, genre blurring is, in fact, a basis for renegotiating the pact between authors and readers, where both sides are well aware of how ambiguous it is to write about an absent third party, realising that it is necessary to omit facts, be concise, make sense of convoluted events, and to extract the essence in things that seemingly look chaotic ${ }^{4}$. It is virtually impossible to adhere to the formerly expected demand for absolute objectivism, since the process of collecting, selecting, interpreting and unveiling data creates an individualised and subjective method of the biographer. The process is also a manifestation of the authors' primary objective, i.e., why they have chosen this particular biographee, and what their reasons are behind the attempt to evaluate their subject.

Sometimes causes and effects of genre blurring are related to mixing competences, weak professionalism and methodological blurring, more and more biographies abandon the traditional format of describing a biographee's life and works, with authors no longer being experts in the realm represented by the biographee ${ }^{5}$. This usually makes the style of narration more accessible, and thus, attractive to a larger number of readers. The authors often gain competences in parallel with their archival search and the collection of information on a given biographee. At times, however, the confrontation of the biographee's life and works with the biographer's experience, knowledge and sensitivity reveals unexpected potential on both sides, perhaps offering new, unexpected insights that are extremely valuable for both readers and specialists.

3 Biography as a hermeneutic task is discussed by Anna Legeżyńska (2019).

4 The initial pact as described by Paul Lejeune (1975); cf. Czermińska 2002.

5 The creation of a biographical story on the basis of a wide array of elements and the changeability of these methods is presented by Anita Całek — cf. Całek 2014. 
This methodological poaching, i.e., deriving and mixing data from seemingly disconsonant sources, theories and disciplines, is not necessarily evidence of dilettantism among modern biographers. On the contrary, it may have some upsides, since it encourages authors to show utmost involvement, go against the flow, break clichés, apply an innovative combination of narrative methods, and above all, it eschews distanced and routine practices. This approach, in turn, increases alertness, makes perception more sensitive, encourages the writer to follow the "inner necessity" rather than the genre's guidelines.

\section{Blurring as an ethical reaction}

The ambiguity involved in presenting somebody absent forces the biographer to apply double coding, i.e., the author must appraise and select the evidence left by the biographee, while looking for their own voice. They not only have to rely on archival investigations and source materials - the biographee's voice, messages, and tangible evidence, but they must also process this intensity, while attempting to liberate themselves from its impact in the search for their own position: to testify for someone else in best faith, but also on their own behalf, taking into consideration their own intuitions, criteria and assessments so that they remain at peace with themselves. In this perspective, the dynamics of a biography depends on constant oscillation between dependence and invention, obligation to and criticality of interpretation. Although biography is a subordinate genre (e.g., to archival data), it is inseparably connected with compromise, decision-making, choice, selection, exclusion, the necessity to marginalise certain data in order to highlight other information, self-censorship born out of doubt, leading to the lack of ability to adjudicate, etc., all while appearing authoritative.

Biographer blurs things - re-evaluate the archives, excite interest, redirect attention along different tracks. One may say that biographical practice can be compared to a collage the separated, collected, torn snippets of data that constitute an arbitrary presentation of a given biographee and their reality are always a part of a greater whole. This textual collage, even when already published and available to readers, may still undergo further transformations. Authors might be contacted by people: correctors, those who remember the facts presented differently, or are in possession of additional information. Because of their stories a biographic narrative is never set in stone, it continues to change, lives its own life, mutates, which can sometimes be seen in subsequent editions of the same publication. Mixing and blurring constituents of the book anew reveals another dimension. Writing a biography is a form of extracting potential history in the sense this practice is defined by Ariella Azoulay, i.e., returning to the archives in search of accounts that were discarded, ignored, or censored, in order to trace abandoned threads and lost connections, and to reconstruct extinct intensity (Azoulay 2019). This not only requires a different mindset and greater inquisitiveness, but also changing the tools applied to select and study the source data. New biographical interpretations draw a lot from the practice of potential histories: they extricate figures from the shadows, presenting them in a different light, revalorising actions taken and achievements gained, highlighting forgotten relationships by occasionally emphasising the stories of the previously dominated, subordinated or dependant parties, surmising motivations, discussing the context behind certain tendencies, and redefining the importance of key events. Carefully following formerly overlooked biographical trails may bring about effects on a global rather than individual scale, as sometimes the main purpose of a biographical narrative is not to present an individual or even a group, but a whole society, an emotional community, or 
to make an intervention for the sake of certain worldview values. In this case, a biographical publication becomes a platform for social criticism, a tool to offer alternative political, economic, class-related scenarios, etc. Biographers rely on the biographee's thoughts, works, activities and accounts, but interpret and reinforce them, showing them in a new light, and quite often supporting or opposing them, expressing criticism, objections, a desire to react, counteract and dispute. Today, it seems unnecessary to inquire whether it is desirable for biographers to add or compare their own perspectives with the biographee's - it is inevitable - even if the author goes to great lengths to reduce or soften these signals.

In practice, the vast majority of biographical publications that have recently been published in Poland try to incite a reaction, entangle and lure readers with intensity, and interest them by turning reading into an adventure. Those successful at this do so not by applying advanced scales of realism or a genuinely recreated world, but through the author's personalised approach to the biographee, the application of the right stylistic devices, and by creating a convincing effect of immediacy. Thus, biographies have become something more than just reading matter to guide readers and be experienced by them; they are now a testimony to the author's involvement. As a result, they intrigue the reader not by means of a biased and subjective depiction, but by juxtaposing and blurring the perspectives of the biographee and the biographer. Biographical narratives show both the past reality, and at the same time, are proof of the contemporary interaction (one that inevitably changes the author): revealing the entanglement, doubts, omissions, misuses and overinterpretations, and, finally, it also divulges how the author yields to the impact of the disparity between themselves and the biographee or distances themselves from this difference. After all, writing a biography does not always mean an empathic immersion in or identification with the presented figure. Arguably, the most interesting cases are those exposed to the mechanism of exotopy (especially, when it occurs on multiple levels) between the author, the biographee, and the reader (cf. Bakhtin 1986, Nycz 2015). In this type of experience, the author does not appropriate the biographee, but undergoes a transition from incomprehension to mindfulness of all that is different, alien, co-creating the context for the biographee's image, a radical image of another person, another self that can never be fully experienced or described by others. Thus, attempts to transcend one's perspective - to understand, give meaning to, and write about someone else's life consist in encountering dissimilarity and exploiting the potential of the resultant difference, i.e., building narration from the experience gap.

\section{Emotional fields}

Although every few years authors and reviewers of non-fictional prose return to the discussion on objectivism, responsibility, accuracy and the ethical obligation imposed on biographers and reporters ${ }^{6}$, there is still need for a serious debate concerning the genre. The clichéd remarks exchanged and expressed during such debates obligate authors to distance themselves, remove any trace of their presence, maintain objectivism and neutrality (perceived as lack of involvement), and yet the clichéd nature of these arguments reduces this discussion to ever lesser importance. It gradually dies down, while authors and books continue to live their own lives among readers. The debate would certainly be more relevant if participants reformulated their questions and stances on the issues to be discussed. For instance, it seems interesting

6 Cf. the paper by Paweł Zajas (2007), who lists the most vital arguments employed during one such discussion. 
to analyse the genre of biography as an emotional field that affects not only the process of reception but also the act of creation. There is no doubt that authors experience emotional turmoil when they understand the dissonance between all that is emotional, physical, and tangible; and all that is intermediary and linguistic, only the latter of which is shared with readers. Unearthed archival information may carry a considerable emotional load, which when encountered and presented by the author - may have equivocal, previously dormant, potential to change minds. The range of these discoveries is enormous: from tangible remains (sometimes literally physical remains) that may trigger extreme reactions, through recorded thoughts, e.g., extremely intimate experiences, to confidential messages and information that may incriminate or compromise a given person.

Having to work on data also means the necessity to process it - to experience it, to absorb certain emotional excesses, and use it in narration, to translate affect into a language that will convey the message or share the emotions with the reader. This task becomes even more formidable when the archival data seem chaotic, meaningless, incomplete, foreign or unmanageable. Tension born out of incomprehension, coupled with an urge to consolidate and make things meaningful seems to be a key incentive determining the dynamics of a biographer's work. Essentially, interpretation, writing on behalf of someone absent; for someone who remembers/commemorates them, or for a general readership is a multistage obligation that creates form out of something formless, something that is elusive and beyond our control - another person's life. We may suggest that biographic works resemble the way a lens operates when it concentrates diffused light. It collects pieces, the most important and yet often unexposed threads, images, and gestures. It may also work like a blurry, frosted glass that softens the light's glare: through appropriate selection, processing and interpretation of data, it reduces excess, conceals all that is unbearable, dazzles or disturbs, thereby protecting the reader against the detritus of someone else's experience, the chaos of fates and fortunes, the nonsense and insipidity of existence.

All this makes the biographer a go-between, perched on an elusive but discernible line between what is affective and emotional, physical and discursive, intimate and public. Thus, unearthing biographic meaning, mediating between the there and then and the here and now, presenting and confirming archival data means, in fact, creating conditions of visibility and audibility, without which a given biographee would not be seen, heard or experienced. And not because they never existed, but because they were somebody else, always somebody else. 


\section{Bibliography}

Azoulay Ariella (2019), Potential History: Unlearning Imperialism, Verso, London-New York. Bachtin Michaił (1986), Estetyka twórczości stownej, trans. D. Ulicka, ed. Czaplejewicz E., Warsaw.

Całek Anita (2014), Biografia naukowa - od koncepcji do narracji. Interdyscyplinarność, teorie, metody badawcze, Wydawnictwo Uniwersytetu Jagiellońskiego, Krakow.

Czermińska Małgorzata (2002), Autobiograficzny trójkąt. Świadectwo, wyznanie i wyzwanie, Universitas, Krakow.

Geertz Clifford (1990), O gatunkach zmąconych: nowe konfiguracje myśli spotecznej, trans. Z. Łapiński, “Teksty Drugie”, no. 2.

Legeżyńska Anna (2019), Wystarczy mocno i wytrwale zastanawiać się nad jednym życiem... Biografistyka jako hermeneutyczne wyzwanie, "Teksty Drugie”, no. 1.

Lejeune Paul (1975), Pakt autobiograficzny, trans. A. W. Labuda, “Teksty”, no. 5.

Nasiłowska Anna (2019), Angielskie, francuskie i polskie tradycje biografistyki. Wprowadzenie do tematu, “Teksty Drugie”, no. 1.

Nycz Ryszard (2015), Inny jak ja (Trzy i pót glosy do aktualnego teoretycznie i praktycznie problemu), "Teksty Drugie", no. 6.

Rosenwein Barbara (2015), Obawy o emocje w historii, trans. J. Wysmułek, “Teksty Drugie”, no. 1. Tabaszewska Justyna (2019), Na granicy faktu. Kategoria faction w badaniach nad wspótczesnymi biografiami, “Teksty Drugie”, no. 1.

Zajas Paweł (2007), Wokót "Kapuścinski non-fiction": próba podsumowania i ewaluacji dyskusji, “Teksty Drugie”, no. 1. 
* Uniwersytet Jagielloński, Wydział Polonistyki ul. Golębia 16,31-007 Kraków

e-mail: agnieszka.dauksza@uj.edu.pl

Badania wykonano przy wsparciu finansowym Priorytetowego Obszaru Badawczego Heritage w ramach Programu Strategicznego Inicjatywa Doskonałości w Uniwersytecie Jagiellońskim, edycja I. 


\section{Zmącone wody żywiołu biograficznego. Wstęp redakcyjny}

\section{Zmącenie gatunkowe i metodologiczne}

Gdy Clifford Geertz formułował koncepcję gatunków zmąconych, pisał o „dzisiejszym skotłowaniu form” (1990: 114), które odpowiada naturze życia pojętego jako „składnica różnych strategii” (s. 119). Rozpoznanie powraca w namyśle nad współczesnym pisarstwem biograficznym, którego poczytność mówi sporo o praktykach czytelniczych wspólnoty. Jednak, czym jest owo zmącenie, na jakich płaszczyznach można je rozpatrywać, o czym świadczy? Z pewnością - jak wskazują badacze gatunku - mącenie biografii jest procesem postępującym i prowadzi do jej spowinowacenia z formami reportażowymi, powieściowymi i autobiograficznymi (por. Całek, Nasiłowska, Tabaszewska 2019). Dochodzi więc - z jednej strony — do wzmożenia funkcji interwencyjnej, krytycznej i „śledczej”, często też do intensyfikowania obecności autora, z drugiej zaś strony umacnia się tendencja do fikcjonalizacji opowieści biograficznej ${ }^{1}$.

Zdaje się jednak, że biografie zawsze były narracjami polifonicznymi i hybrydycznymi łączyły praktyki interpretacji elementów tekstowych, wizualnych, materialnych i wspomnieniowych, używały analizy historycznej, literaturoznawczej, psychologicznej i z zakresu historii sztuki, włączały formy naukowe, epistolarne i — szerzej — intymistyczne, balansowały między reprezentowaniem danej postaci i inwencyjnym tworzeniem (nieco) innego wyobrażenia o jej działaniach - nawet gdy skrupulatnie zacierały obecność subiektywnej perspektywy piszącego. Kluczowe jest jednak pytanie nie tylko o to, jak pasożytnicze biografie wykorzystują inne gatunki, ale przede wszystkim, w jakim celu takie metody są stosowane. Przypadki należy rozpatrywać kontekstowo w zależności od zmiennych strategii poszczególnych biografów, ale generalnie rzecz biorąc luzowanie czy też zagęszczanie formy biograficznej — zależy jak interpretować współczesne przemiany gatunku — z pewnością jest wyrazem poszukiwania formy bardziej pojemnej. Pojemnej - to znaczy takiej, dzięki której będzie można stworzyć przekonujący obraz danego bohatera lub bohaterki.

1 O postępującej fikcjonalizacji gatunku biograficznego i o formie faction pisze Justyna Tabaszewska (2019). 
Zasadniczo współczesne polskie pisarstwo biograficzne wpisuje się w dość określone typy budowania opowieści - są to albo narracje pretendujące do miana ujęć całościowych, utrzymane w konwencji realistycznej i zapewniające o prawdziwości wszystkich elementów prezentowanego świata, albo narracje, które decydują się na fragmentaryczność, skupiają się na wybranym aspekcie czyjejś działalności lub ukazują życie w konkretnej relacji. Fragmentaryczność ujęcia idzie niekiedy w parze z inwencyjnością formalną — poszukiwaniem środków, które oddawałyby czy raczej tworzyłyby „efekt” danej postaci, nawiązywały w jakiś sposób do jej praktyki literackiej czy artystycznej. Forma odpowiednio pojemna to również przestrzeń do realizacji stawki przyjętej przez autora biografii - próby odpowiedzi na przewodnie pytanie, mnożenia hipotez dotyczących postawionego problemu badawczego, realizacji założonych celów itd. Zmącenie biografii może równie dobrze wynikać z napięcia między tymi motywacjami - wyartykułowanymi lub nieuświadamianymi przez biografa. Oczywiście piszący także podlegają modom recenzenckim, wymogom rynkowym, sugestiom wydawniczym, zobowiązaniom wobec spadkobierców i wreszcie presji oczekiwań „strażników pamięci”, wspólnocie pamiętających i kanonowi wyobrażeń na temat danego bohatera. Biografie nigdy nie powstają w próżni, to niby oczywistość, ale być może jak żaden inny gatunek są obciążone ciężarem odpowiedzialności wobec bohatera i archiwum, zobowiązaniem skrupulatności, adekwatności i jednocześnie pewnej inwencyjności czy atrakcyjności przekazu.

Biorąc pod uwagę relacyjność tekstu biograficznego i poziomy uwikłania piszącego we wspólnotę zależności symbolicznych, materialnych, politycznych i pamięciowych, można by spytać: zatem jakie społeczeństwo, takie biografie? Niekoniecznie, ale owo „skotłowanie” formy biograficznej - elementy i charakter ich powiązań - rzeczywiście pośrednio wskazują na oczekiwania, nawyki percepcyjne i ramy doświadczeniowe twórców oraz odbiorców. $\mathrm{Z}$ pewnością popularność biografii nie jest nową modą. Pytanie jednak, co sprawia, że w dobie zbiorowego narodowego nieczytania czytelnicy decydują się od czasu do czasu sięgnąć po książkę biograficzną - co wiadomo przecież nie tylko z ich deklaracji, ale i ze stosunkowo wysokich nakładów. Ryzykując nadmierne uproszczenie, można wyróżnić kilka podstawowych przyczyn.

Po pierwsze, chodzi zapewne o potrzebę autentyzmu i bezpośredniości, poczucie bliskości z przedstawianą postacią, złudzenie uczestnictwa czytelnika w prezentowanych realiach. Biografia to przecież „pisanie życia”, na co wskazuje grecki źródłosłów. Pisanie życia i też jego kreowanie - nie tylko przez autora, ale i odbiorcę, który w akcie lektury sprawczo aktualizuje sensy, nieuchronnie wchodzi w rolę świadka ciągłości wydarzającego się życia. Po drugie, pisanie i czytanie biografii to także zapuszczanie sondy w inne, skądinąd niedostępne nam epoki, grupy i środowiska społeczne, które nagle przestają być abstrakcyjnym tłem, są zaś konkretnym, złożonym, niekiedy fascynującym kontekstem współtworzącym doświadczenie jednostki. Istotny jest aspekt poznawczy, ale i próba odczucia tamtych realiów - mam tu na myśli niemal detektywistyczne zadanie rekonstruowania z materiałów archiwalnych standardów funkcjonowania danej wspólnoty afektywnej - norm, motywacji i scenariuszy zachowań emocjonalnych, na tle których tym wyraźniej prezentują się losy bohaterki lub bohatera biografii ${ }^{2}$.

Po trzecie, bywa, że satysfakcja z lekturowego spotkania z taką postacią wynika z chęci przekroczenia ram własnego doświadczenia, ciekawości cudzych, nieraz odległych i barw-

2 Por. koncepcję badań nad wspólnotami emocjonalnymi proponowaną przez Barbarę Rosenwein (2015). 
nych spraw. Ta dążność może wiązać się także z potrzebą identyfikacji — czytelniczego złudzenia, że oto wchodzi się w skórę jakoś wyróżniającej się postaci i widzi świat jej oczami. Może być jeszcze inaczej - zamiast identyfikacji pojawiałby się odruch podglądactwa, voyeurystycznej przyjemności ze śledzenia tego, co osobiste. Oczywiście wiąże się z tym problemem kolejny wymiar funkcjonowania biografii: traktowanie postaci jako fenomenu, którego życiorys, specyficzne cechy, zachowania, praktyki i działalność mogą posłużyć za inspirację dla współczesnej wspólnoty odbiorców. Bywa także, że ujęcie biograficzne ułatwia zrozumienie czyjejś twórczości, przekierowuje jej odbiór na inne tory, demistyfikuje dotychczasowy obraz lub dekonstruuje wizerunek pielęgnowany za życia bohaterki czy bohatera.

Czy jednak rzeczywiście potrzeby czytelnicze sprowadzają się przede wszystkim do odczucia autentyzmu? Sądząc po ilościach sprzedanych egzemplarzy, obiegowych opiniach, komentarzach internetowych i profesjonalnych recenzjach tym, co decyduje o sukcesie danej opowieści biograficznej, jest raczej umiejętne łączenie nietożsamych elementów - nie tyle odtwarzanie znanych faktów i motywów, ile ich konfrontowanie z tym, co nieoczywiste, przekraczające wyobrażenia o danej postaci i wychodzące poza ustalony zestaw ocen. Chodzi również o mediowanie między różnymi nośnikami i przekaźnikami informacji, kreatywność pisarskiej reakcji na dane archiwalne — mącenie zastanych źródeł. Z tej perspektywy pisanie biografii to wzniecanie ruchu, aktualizowanie sensów czyjegoś doświadczenia i włączanie ich we współczesne doświadczenie odbiorcze ${ }^{3}$. Wielce prawdopodobne, że kluczowe okazuje się więc nie sugerowanie prawdziwości przedstawianych realiów, ale umożliwienie odbiorcom immersji, zanurzenia w nurcie opowieści, spowodowanie, że lektura staje się znaczącym przeżyciem. Angażowanie nietożsamych gatunków, łączenie form niefikcjonalnych i chwytów typowych dla narracji powieściowych zdaje się nieodzowne. Zmącenie gatunkowe jest więc $\mathrm{w}$ istocie podstawą renegocjacji paktu między twórcami i czytelnikami — obie strony są świadome niejednoznaczności pisania o kimś nieobecnym, zdają sobie też sprawę z konieczności redukcji faktów, wyciszania nadmiaru, wygładzania chropowatości zawiłych wydarzeń, szukania sensu w czymś, co niekiedy jawi się jako bezładne ${ }^{4}$. Trudno upierać się przy niegdyś stale podnoszonym wymogu obiektywizmu biografa — choćby dlatego, że praca doboru i selekcji materiałów, ich interpretacja i sposoby eksponowania są przecież zindywidualizowaną, subiektywną metodą, tworzą warsztat, świadczą też o zasadniczej kwestii, czyli autorskiej stawce, przyczynie wyboru tej, a nie innej postaci i o powodach, dla których podejmuje się próbę zmiany jej statusu.

Przyczyny i konsekwencje mącenia gatunkowego łączą się z pomieszaniem kompetencji, „słabym profesjonalizmem” czy zmąceniem metodologicznym - coraz częściej biografie odchodzą od tradycyjnej formuły opisywania „życia i twórczości”, a jej autorzy nie są badaczami biegłymi w dziedzinie reprezentowanej przez bohatera książki ${ }^{5}$. Zdobywanie kompetencji wydarza się więc niemal równolegle z kwerendą archiwalną i pozyskiwaniem informacji na temat danej postaci. Efektem jest zwykle bardziej popularny charakter narracji, co wiąże się z rozszerzeniem kręgu potencjalnych odbiorców. Bywa jednak i tak, że twórczość bohatera w spotkaniu z doświadczeniami, wiedzą i wrażliwością biografa otwiera nieprzeczute

3 O biografistyce jako zadaniu hermeneutycznym pisze Anna Legeżyńska (2019).

4 Za pakt wyjściowy rozumiem układ scharakteryzowany przez Paula Lejeune (1975); por. Czermińska 2002.

5 O splataniu opowieści biograficznych z wielu nietożsamych elementów i o zmienności tych metod pisze Anita Całek (2014). 
potencjały obu stron i zyskuje nowe odczytania, nieoczywiste a wartościowe dla profesjonalnych czytelników.

Tak pojęte „kłusownictwo” metodologiczne - czerpanie i miksowanie danych z pozornie nieprzystających słowników, teorii i dyscyplin — nie musi być dowodem na dyletanctwo współczesnych biografów - przeciwnie, ma swoje atuty. Wiąże się bowiem ze wzmożeniem zaangażowania piszącego, zmusza do patrzenia w poprzek i wbrew utartym schematom, prowokuje do inwencyjnego łączenia metod opisu, a nade wszystko utrudnia zdystansowane, rutynowe działania. Takie podejście zaś wzmaga czujność i uważność, uelastycznia percepcję, zachęca do pisania w zgodzie nie tyle z wytycznymi gatunku, ile z „koniecznością wewnętrzną" (Geertz 1990: 115).

\section{Mącenie jako odruch etyczny}

Dwuznaczność wpisana w gest reprezentowania kogoś nieobecnego zmusza autora/autorkę do podwójnego kodowania: bycia zależnym od tropów bohatera/bohaterki i jednocześnie poszukiwania własnego głosu. Zatem z jednej strony jest zdawanie raportów z pracy archiwalnej, podleganie wpływowi materiałów źródłowych — głosowi bohatera, jego przekazowi, śladom materialnym. Z drugiej strony jest przepracowywanie tych intensywności, próba emancypacji spod tego wpływu, szukanie własnej pozycji nadawczej, świadczenie o kimś w najlepszej wierze, ale i w swoim imieniu, poprzez własne intuicje, kryteria i oceny, w zgodzie ze sobą. W tej perspektywie dynamika biografii zależy od ciągłej oscylacji między zależnością i inwencją, zobowiązaniem i krytycznością interpretacji. Biografia jest gatunkiem zależnym, może wręcz służebnym (np. wobec danych archiwalnych, kanonu wspomnień i wyobrażeń wspólnoty), a zarazem wiąże się z gestem autorytarnym autora, kompromisem, decyzją, wyborem, selekcją, pominięciem, koniecznością marginalizowania jednych materiałów i eksponowania czy wyciszania innych, autocenzurą wynikającą na przykład z wątpliwości czy niemożności rozstrzygnięcia.

Biograf jest mącicielem - porusza archiwum, prowokuje zainteresowanie, przekierowuje uwagę na inne tory - a jednocześnie sam podlega zmąceniu. Określenie ma zresztą więcej odcieni: mącić znaczy burzyć, bełtać, mieszać zastane elementy, ale i zakłócać spokój, niepokoić, intrygować. Skupiając się na pierwszym aspekcie, można stwierdzić, że praktyka biograficzna wiele ma z układanki kolażowej — odnalezione, pozyskane, wydarte skrawki informacji tworzą arbitralną prezentację danej postaci i jej realiów — są zawsze fragmentem większej całości. Układanka tekstowa - nawet już opublikowana, przejęta przez wspólnotę czytelniczą - podlega zaś procesowi dalszych przekształceń, do autorów biografii zgłaszają się kolejne strony: informatorzy, poprawiacze, pamiętający inaczej, dysponujący innym zestawem danych - ich opowieści sprawiają, że narracja biograficzna nigdy nie jest domknięta, żyje, zmienia się, mutuje, co niekiedy można obserwować w kolejnych wydaniach książki. Mieszanie, zestawianie składników na nowo zyskuje jednak jeszcze inny wymiar. Pisarstwo biograficzne to również forma potencjalizowania historii w sensie, jaki nadaje tej praktyce Ariella Azoulay: powrotu do archiwów w poszukiwaniu narracji dotychczas wykluczanych, niedostrzeganych lub cenzurowanych, by śledzić zaniechane scenariusze i wytracone połączenia, odtwarzać wygasłe intensywności (Azoulay 2019). Chodzi zatem o przekierowanie percepcji, dociekliwość, ale i zmianę narzędzi doboru i badania materiałów źródłowych. Nowe odczytania biograficzne wiele czerpią z praktyki historii potencjalnych: wydobywają postacie z cienia, by przedstawić je w innym świetle, rewaloryzują cudze działania i osiągnięcia, od- 
twarzają zapomniane relacje, niekiedy kładąc nacisk na opis stron wcześniej zdominowanych, podległych czy zależnych, domniemają motywacje, dyskutują kontekst zainicjowania określonych tendencji, redefiniują znaczenie kluczowych wydarzeń. Czujne tropienie wcześniej prześlepionych odnóg biograficznych miewa również ponadjednostkowe konsekwencje. Wypada tutaj przypomnieć o drugim znaczeniu „mącenia” jako czynności zakłócającej bieg rzeczy, niepokojącej. Bywa, że stawką narracji biograficznej jest nie tylko prezentacja indywidualnego bohatera/bohaterki czy grupy aktantów, całego środowiska, wspólnoty emocjonalnej, ale też chęć interwencji, działanie na rzecz określonych wartości światopoglądowych. Książka biograficzna staje się wówczas polem krytyki społecznej, narzędziem forsowania innych niż przyjęte scenariuszy politycznych, klasowych, ekonomicznych itd. Biografowie bazują na myśli, dorobku, działalności, przekazie bohatera/bohaterki, interpretują je, wzmacniają, aktualizują ich sensy, a nierzadko też łączą się z nimi lub ścierają, wyrażają krytykę, sprzeciw, chęć reakcji, przeciwdziałania, dyskusji. Nie ma już dziś większego sensu pytać, czy takie łączenie lub konfrontowanie perspektyw jest w pracy biograficznej wskazane: jest to nieuniknione, nawet jeśli piszący wkłada wiele wysiłku, by takie sygnały redukować czy wyciszać.

W praktyce większość pozycji biograficznych wydawanych w ostatnich latach na polskim rynku stara się wzniecać ruch, wikłać odbiorców, przyciągać intensywnościami, interesować poprzez oferowanie czytelniczej przygody. Te, którym to się faktycznie udaje, przekonują nie tyle zaawansowaniem skali realizmu czy prawdziwością kreowanego świata, ile autentyzmem spersonalizowanego podejścia autora/autorki do danej postaci, znalezieniem odpowiedniego chwytu, wytworzeniem przekonującego efektu bezpośredniości. Jako takie biografie stają się więc nie tylko lekturami-doświadczeniami i przewodniczkami dla czytelników, ale i świadectwem zaangażowania osoby piszącej. W rezultacie intrygują — to kolejny aspekt mącenia nie pomimo stronniczości i subiektywności ujęcia, ale właśnie dzięki takiemu spotkaniu perspektyw: bohatera(-rki) i autora(-rki) biografii. Narracja świadczy o minionych realiach i jednocześnie jest świadectwem współczesnej interakcji, która nieuchronnie zmienia tego, kto pisze: ukazuje jego uwikłanie, wątpliwości, zaniechania, nadużycia i nadinterpretacje, wreszcie uleganie wpływowi różnicy lub dystansowanie się od takiej siły. Pisanie biograficzne niekoniecznie jest ofertą empatycznego zanurzenia czy identyfikacji z prezentowanym obiektem. Najciekawsze są chyba przypadki, w których działa mechanizm niewspółobecności, egzotopii - i to na kilku poziomach: między piszącym, opisywanym oraz czytającym (por. Bachtin 1986; Nycz 2015). Tego typu doświadczenie sprawia, że autor/autorka nie zawłaszcza persony biograficznej, ale dokonuje przejścia od niezrozumienia do uważności wobec tego, co odmienne, obce, współtworzące kontekst funkcjonowania danej postaci. Postaci, która przecież zawsze jest radykalną obcością, jest sobą do granic, których nie sposób odczuć i opisać. Próby wyjścia poza własną perspektywę - zrozumienia, nadawania sensu, pisania cudzego życia - polegają więc na zderzeniu się z odmiennością i wyzyskiwaniu potencjału tak powstałej różnicy: budowaniu narracji z wyrwy doświadczenia.

\section{Pola emocjonalne}

Co kilka lat w gronie twórców i recenzentów prozy niefikcjonalnej powraca dyskusja o obiektywizmie, odpowiedzialności, precyzji oraz zobowiązaniu etycznym biografów i reportażystów $^{6}$. Zdaje się jednak, że poważna debata na temat gatunku biograficznego dopiero przed

6 Por. tekst Pawła Zajasa (2007) zbierający najważniejsze argumenty jednej z tych dyskusji. 
nami. Gdy padają rutynowe uwagi zobowiązujące piszących do zdystansowania, wycofania śladów autorskiej obecności, bezstronności i obiektywizmu pojętego jako brak zaangażowania, wymiana zwykle staje się wtórna, wycisza się samoistnie, a piszący i ich opowieści żyją dalej własnym życiem czytelniczym. Dyskusja z pewnością zyskałaby na aktualności, gdyby nieco przeformułować stawiane pytania i problemy. Ciekawy zdaje się potencjał rozpatrywania biografii jako pola emocjonalnego oddziałującego nie tylko w perspektywie odbiorczej, ale również w procesie twórczym. Zmącenie emocji niewątpliwie staje się udziałem autorów - chodzi o odczuwanie dysonansu między tym, co afektywne, cielesne, materialne i tym, co zapośredniczone, językowe, co ma stać się udziałem wspólnoty czytelników. Znaleziska archiwalne miewają znaczny ładunek afektywny, który — niekiedy unieruchomiony, „zamrożony” przez lata - w bezpośrednim kontakcie aktualizuje swój niejednoznaczny potencjał. Repertuar takich obiektów jest ogromny: od resztek materialnych, czasami dosłownie cielesnych, mogących generować reakcje abiektualne, przez zapisy czy ślady skrajnie intymnych doświadczeń, tajone wcześniej poufne wiadomości, po informacje obciążające czy kompromitujące daną postać.

Konieczność opracowania takich danych to jednocześnie konieczność ich przepracowania — odczucia, przyjęcia na siebie pewnej nadwyżki afektywnej i zrobienia z niej użytku narracyjnego, przekładu intensywności na język przekazywalnego komunikatu lub emocji możliwych do współdzielenia przez czytelników. Zadanie tym trudniejsze, gdy to, co odnalezione w archiwum, zdaje się bezładne, bezsensowne, niekompletne, dziwne czy niemożliwe do opanowania. Napięcie między nierozumieniem a koniecznością scalania i nadawania sensu jest chyba kluczowym bodźcem decydującym o dynamice pracy biografa. Interpretacja relacyjna, pisanie wobec kogoś nieobecnego, kogo próbuje się reprezentować, jednocześnie w odniesieniu do wspólnoty pamiętających/świadczących i z przeznaczeniem do lektury potencjalnych czytelników, w gruncie rzeczy okazuje się wielostopniowym zobowiązaniem, by tworzyć formę z czegoś bezforemnego: z cudzego, zawsze wymykającego się, niesfornego życia. Praca biograficzna przypomina zatem nie tylko pracę soczewki skupiającej rozproszone fragmenty, najważniejsze, choć dotychczas niekoniecznie eksponowane wątki, obrazy i gesty. Działa również jak szkło mącone osłaniające źródła światła: poprzez odpowiedni dobór, selekcję, opracowanie i interpretację wytłumia nadmiar, przesłania to, co nieznośne, oślepiające, zaburzające percepcję, chroni odbiorców przed miazgą cudzego doświadczenia, bezładem przeżyć, chaosem losów, bezsensem czy nijakością egzystencji.

Zatem biografowie to pośrednicy lokujący się na trudnej do uchwycenia, ale wyczuwalnej granicy między afektywnym (bardziej prymarnym, cielesnym, intensywnym, pobudzeniowym) i emocjonalnym (ustabilizowanym znaczeniowo, usankcjonowanym społecznie jako konwencja odczuwania), materialnym i dyskursywnym, intymnym i publicznym. Aktualizowanie znaczeń biograficznych, mediowanie między tam i wtedy a tu i teraz, reprezentowanie i świadczenie o zawartości archiwów jest więc w istocie kształtowaniem tego, co zmysłowe, kreowaniem warunków widzialności i słyszalności, bez których nie można danej postaci na nowo zobaczyć, usłyszeć i odczuć. Nie dlatego, że nie istniała, ale dlatego, że była kim innym, zawsze kim innym. 


\section{Bibliografia}

Azoulay Ariella (2019), Potential History: Unlearning Imperialism, Verso, London-New York. Bachtin Michaił (1986), Estetyka twórczości stownej, przeł. D. Ulicka, opr. przekładu i wstęp Czaplejewicz E., Warszawa.

Całek Anita (2014), Biografia naukowa - od koncepcji do narracji. Interdyscyplinarność, teorie, metody badawcze, Wydawnictwo Uniwersytetu Jagiellońskiego, Kraków.

Czermińska Małgorzata (2002), Autobiograficzny trójkąt. Świadectwo, wyznanie i wyzwanie, Universitas, Kraków.

Geertz Clifford (1990), O gatunkach zmąconych: nowe konfiguracje myśli spotecznej, przeł. Z. Łapiński, „Teksty Drugie”, nr 2.

Legeżyńska Anna (2019), Wystarczy mocno i wytrwale zastanawiać się nad jednym życiem... Biografistyka jako hermeneutyczne wyzwanie, „Teksty Drugie”, nr 1.

Lejeune Paul (1975), Pakt autobiograficzny, przeł. A.W. Labuda, „Teksty”, nr 5.

Nasiłowska Anna (2019), Angielskie, francuskie i polskie tradycje biografistyki. Wprowadzenie do tematu, „Teksty Drugie”, nr 1.

Nycz Ryszard (2015), Inny jak ja (Trzy i pót glosy do aktualnego teoretycznie i praktycznie problemu), „Teksty Drugie”, nr 6.

Rosenwein Barbara (2015), Obawy o emocje w historii, przeł. J. Wysmułek, „Teksty Drugie”, nr 1.

Tabaszewska Justyna (2019), Na granicy faktu. Kategoria "faction” w badaniach nad wspótczesnymi biografiami, „Teksty Drugie”, nr 1.

Zajas Paweł (2007), Wokót „Kapuścinski non-fiction”: próba podsumowania i ewaluacji dyskusji, „Teksty Drugie”, nr 1. 